\title{
Attitudes and Soft-Skills Acquired from Accounting Internship; Does It Affect the Academic Performance?
}

\author{
Bedah AHMAD, Nadiah ABD HAMiD, Zarinah ABDUL RASiT and \\ Norazian HUSSIN
}

Universiti Teknologi MARA, Malaysia

Correspondence should be addressed to: Bedah AHMAD; bedah728@uitm.edu.my

Received date:17 March 2021; Accepted date: 6 July 2021; Published date: 17 November 2021

Academic Editor: Hezlina Mohd Hashim

Copyright (C) 2021. Bedah AHMAD, Nadiah ABD HAMID, Zarinah ABDUL RASiT and Norazian HUSSiN. Distributed under Creative Commons Attribution 4.0 International CC-BY 4.0

\begin{abstract}
The evolution of financial reporting and information technology disruption has increased challenges in the accounting profession. Accounting practitioners have raised concerns that accounting graduates seem to possess sufficient technical knowledge, but somehow, they lack the required soft skills such as communication and analytical thinking. The accounting program must address issues on technical, soft skills and ethical issues reflecting the graduates. Since the internship program is part of an accounting degree requirement, this study provides an insight on the differences in attitude and soft skills acquired through internship programs between different types of employers; audit firms, and non-audit firms and between genders. The study also examines whether the attitudes and soft skills competencies acquired would affect the academic performance. Students' attitudes and soft skills were assessed using structured questionnaires on 224 accounting students of the Malaysian Public University who had undergone their six-month internship period. The attitudes and soft skills assessed include general skills and motivation, job competency, interpersonal skills, responsibility, trainees' knowledge and ability to communicate. The results provide evidence of an improvement in all the dimensions of attitudes and soft skills except for job competency when having an internship in audit firms rather than non-audit firms. Female students showed better performance in all the dimensions based on a comparison between genders. The findings imply that the internship program is significantly affecting the academic performance, being able to prepare graduates with the necessary technical skills and soft skills to face challenges in the accounting profession.
\end{abstract}

Keywords: Attitude, Soft Skills, Accounting Internship, Academic Performance.

Cite this Article as: Bedah AHMAD, Nadiah ABD HAMID, Zarinah ABDUL RASIT and Norazian HUSSIN (2021), "Attitudes and Soft-Skills Acquired from Accounting Internship; Does It Affect the Academic Performance?", Journal of Southeast Asian Research, Vol. 2021 (2021), Article ID 718716, DOI: $10.5171 / 2021.718716$ 


\section{Introduction}

In line with the Ministry of Higher Education's policy related to the development of the national policy on internship, it has made it compulsory for all universities in Malaysia, including public and private universities, to embed the internship program in the curriculum design to comply with the requirement for the academic degree curriculum (Dasar Latihan Industri, IPT and KPT, 2010). The internship program was highlighted as one of the blueprints in the Malaysian National Development Plan 20152025 , with 2U2I (2 years in university and two years in the industry) and 3U2I (3 years in university and one year in the industry). The internship programs can help students connect classroom learning with real-world experience (Anjum, 2020). It is acknowledged that an internship bridges the gap between the academic training and the practical application of theoretical understanding by providing practical on-the-job experience (Jawabri, 2017). It is common for an employer to have certain expectations of a graduate in terms of being ready with knowledge and related skills when entering the job market.

Nowadays, the accounting profession becomes more complex and requires accounting graduates to be more competent and to have job-related skills to enhance their market ability (Penafort and Ahmad, 1997; Abel \& Su, 2014). Accounting graduates are not only expected to be excellent in the academic performance, but they are also expected to possess team work and leadership skills, written and oral communication skills, analytical skills, time management skills, information technology skills, and interpersonal skills (Ismail et al., 2020).

Hence, the accounting internship program should offer significant benefits to accounting graduates to become more capable of transferring knowledge through working experience in the host organization.
Internships are thought to support students in terms of career analysis and preparation, recognizing the role of accounting within an organization, and integrating it into a professional network (Albu et al., 2016). A variety of timely practical consequences for both universities and host organizations wish to utilize the internship programs as a pipeline for accessing new graduate talents as they strive to maximize internships to facilitate the university-to-work transition (Rose, 2017).

Universities provide internships for students and employers are engaged in the process as the host organization is crucial and essential to comprehend the successful internship objectives, namely to become a win-win situation for all parties. Hurst and Good (2010) asserted that internships are an ideal recruitment opportunity for the employers, as they offer current information of knowledgeable staff, allowing employers to 'preview' the skill sets of prospective employees. Other advantages include employers' opportunity to have extra labor capacity to fill the employment needs or seasonal workload demand at lower costs than those of the permanent staff. Employers' feedback is critical to determine whether the students can carry out their duties during the internship. It helps the university to identify whether its curriculum meets the industry needs and can generate accounting graduates with all aspects of accounting knowledge.

Most of the previous studies focused on the benefits of the internship program from both students' and employers' perceptions which include the relationship between the internship program, and students' performance, acquisition of knowledge, and improved soft skills. However, the existing literatures also revealed that employers are not satisfied with the employability (or "generic") skills of undergraduate students (Hadiyanto and Ibrahim, 2013; Cheng et al, 2016). Studies highlighted that the existing university curriculum has not sufficiently

Bedah AHMAD, Nadiah ABD HAMID, Zarinah ABDUL RASIT and Norazian HUSSIN, Journal of Southeast Asian Research, DOI: 10.5171/2021.718716 
provided the generic skills such as communication and analytical thinking to students. Most studies suggest that the development of these soft skills is best facilitated by providing students with opportunities for internship programs (Jackling and Natoli, 2015; Heang et al., 2019).

This paper would provide further insights about the benefits of the internship program based on the assessments of the attitudes and soft skills competencies. The research also examines whether the attitudes and soft skills competencies acquired during the internship program influence the subsequent academic performance. In particular, the objectives of this study are as follows:

(1) To examine the differences in students' attitudes and soft skills competency undergoing internship programs in audit and non-audit firms.

(2) To examine the differences in students' attitudes and soft skills competency undergoing internship programs between different genders.

(3) To investigate the influence of a students' attitude and soft skills acquired on the internship program and subsequent students' performance.

By examining the employer's assessment of the accounting students' attitudes and soft skills, it is hoped to provide some insights on improving the employability of accounting graduates in Malaysia. The next section of this paper provides reviews of the relevant prior literature, followed by the research method and discussion of the findings. The paper ends with limitations and suggestions for future research.

\section{Literature Review}

\section{Student's Attitudes and Soft Skills Acquired in Internship Programs}

Incorporating the internship program in the university degree program structure has a main objective, which is to expose the students to the real work environment. The accounting internship program provides many benefits to accounting graduates to become more capable of transferring knowledge through working experience in the host organization (Chu and Kwan, 2012; Bukaliya, 2012). It includes developing fundamental communication, interpersonal, teamwork, problem-solving, analytical skills, and independence to work under minimal supervision. Students may also find the relevance of practical knowledge gained in the real working environment to the theory they learned in the classroom (Mohd Jaffri et al., 2011; Paisey and Paisey, 2010). Another primary objective of the internship program is to gather feedback from the employer about the job market, particularly employers' expectations on accounting graduates. The information may help the faculty and university to ensure that the curriculum content is relevant and suitable to prepare students for the current employment needs (Adebakin, 2015; Ismail et al., 2016; Ismail et al., 2020).

Beside exposing students to the real-world working environment, to bridge the gap between theory learned in the classroom and practice, the internship program helps shape personal qualities and business values. Moghaddam (2014) evaluated ten categories of values, namely honesty, respect; integrity, and ethics; accountability, reliability, punctuality, and dependability; environment, and community; cooperation and support; concern for the customer, workforce diversity; high-quality process, product, and service; and productivity. These values are positively correlated with the students' personality traits in terms of their need for achievement, need for affiliations, and goal orientation. Hence, the internship program benefits the students and other stakeholders such as the university and employers as the host organization. These stakeholders perceived that the internship program provides the students with the development of both the technical and soft skills. The three essential components of soft skills developed through the internship program include

Bedah AHMAD, Nadiah ABD HAMID, Zarinah ABDUL RASIT and Norazian HUSSIN, Journal of Southeast Asian Research, DOI: 10.5171/2021.718716 
communication, leadership, and teamwork (Maelah et al., 2014; Moghaddam, 2014).

Several studies identified the necessary skills and characteristics that accounting students must have from the perspective of employers. In the accounting profession, skills like analytical or problem solving, real-life experience, and basic accounting skills are among the top three skills expected by most employers, together with the job generic skills such as written skills, communication skills, teamwork, and professional skills. There are significant differences in the acquisition of knowledge, soft skills, and personal quality of the students before and after they participated in the internship program, which is consistent with other studies (Martin and Wilkerson, 2006; Kavanagh and Drennan, 2008; Yusof et al., 2012; Maelah et al., 2012; Thirumanickam and Ahmad, 2013; Washor, 2015; Bedah et al., 2018). The results suggest that the students' knowledge, soft skills, and personal qualities improved after undertaking the internship program.

\section{Effect of Student Internship Program on Subsequent Academic Performance}

Bedah et al., (2018) found a significant positive correlation between acquiring knowledge such as financial accounting and reporting, taxation and company secretarial, as well as soft skills, and the personal qualities of the students, before and after participating in the internship program. After attending internship programs, students show better performance when continuing the subsequent semester for their final year studies. The findings are also supported by the feedback gathered from the final semester lecturers. Lecturers identified the improvement in the students' responsiveness, participative action, interest, and knowledge level during classroom discussions. Lecturers also observed that students participated well during the lecture and showed interest in providing better solutions, which indicated increased knowledge acquisition.
Ebied (2004) investigated whether an accounting internship improves the academic performance in subsequent coursework of final semester students who have undergone internship programs in. The researcher observed intern versus non-intern students and gathered subsequent grades for them. The results suggested that internship students' grades showed improvement after the internship. Furthermore, internship students exhibited significantly superior grade performance in accounting courses in comparison to non-interns.

Knechel and Snowball (1987) also studied the impact of students' internships on the subsequent academic performance. The research compared a group of students with internship experience to a group of noninterns. The findings contradicted those from Ebied (2004) who suggests that the postinternship course average performance, across all courses, did not differ significantly. Nevertheless, for auditing coursework (where substantive knowledge gained from students' internship experience should be most applicable), interns' performance is considerably better than non-interns. Most interns who are assigned at the audit firm give more significant benefits to the auditing coursework. The argument for contradictory results suggests that the difference between the curriculum structure and the internship program timing has variations in the subsequent academic performance. The University of Florida, under the study of Knechel and Snowball (1987), conducted an internship program in the second last semester, shortly before graduation (average pre-internship credit hours 112). The UAE University, according to the study of Ebied (2004), is more flexible, as it allowed students to undertake the internship program much earlier (average pre-internship credit hours 90). The difference suggests that students with fewer academic credit hours may benefit more than those with high academic credit hours.

Bedah AHMAD, Nadiah ABD HAMID, Zarinah ABDUL RASIT and Norazian HUSSIN, Journal of Southeast Asian Research, DOI: 10.5171/2021.718716 
Thilakerathne and Madurapperuma (2014) examined the effect of accounting student internship programs on the subsequent academic performance in one of the national universities in Sri Lanka. The university performance assessment was based on the average GPA of the students. It is revealed that the internship programs boost learning outcomes as measured by improved year GPA averages. Mohd Nor and Ismail (2015) reported that students with good internship results would perform better in their subsequent accounting courses (auditing and taxation courses). The results imply that students perform better in their overall academic performance and in the courses as they are closely relevant to their assignments during the internship program. The research provides evidence that students' exposure to real work environment could enhance their understanding and learning.

Martin and Wilkerson (2006) examined the changes in student's knowledge and attitudes resulting from the pre and post-internship experiences. The internship program was found to have a positive effect on the knowledge as it provides better understanding of accounting courses. Nevertheless, even though internship experiences enhanced their knowledge and skill base, little improvement was identified in their academic motivation.

\section{Research Methodology}

\section{Population and Sample}

The population of the study is the semester seven students of the Bachelor of Accountancy program of a public university in Malaysia. The course structure at this university requires students to undergo an internship program during their seventh semester. They would return to the university to register their final semester study upon completing the six-month internship program. Since the students have another semester after completing the internship program, they have the opportunity to apply and share their knowledge and experience gained during internships with others in the classroom. A total of 247 questionnaire surveys were distributed to the internship employers via accounting internship students. A total of 224 completed the questionnaire, and useable surveys were collected at the end of the internship period. All of the 224 questionnaires are valid and useable.

\section{Research Instrument}

This internship program is part of the Bachelor of Accountancy requirement as stipulated by the Malaysian Institute of Accountants. For data collection, each student was given a Practical Training Evaluation Form by the employer before registering as a trainee at the host organization (internship employer). The form is used as an assessment of attitudes and soft skills competency. The internship employers, who are the respondents of the survey, need to assess each student undergoing the internship at their premises for the period of six months. Sections $\mathrm{A}$ to $\mathrm{C}$ of the form consist of demographic information which includes the student's name and contact number, employer's name, address, and internship period. Section D consists of Likert-type questions ranging from 1 (poor) to 5 (excellent) to measure the employers' assessment relevance of attitudes, and soft skills competency. It comprises eight (8) elements; general skills and motivation, job competency, interpersonal skills, responsibility, compliance with working requirements, the trainee's knowledge and understanding of concepts, and communication skills. The last section provides open-ended questions which require the employer to provide feedback on the trainee's strengths and weaknesses, and other relevant comments that the internship employer would like to highlight about the trainee. 


\section{Data Analysis}

The data gathered were analysed using Statistical Packages for Social Science (SPSS) to produce the descriptive statistic and to conduct paired sample T-Test analysis. The descriptive statistics were used to determine the mean and median scores of the attributes. The reliability test was also conducted on the variables to determine Cronbach Alpha for testing the reliability of the instrument used. The regression analysis results explain the variation in the relationship between students' performance and soft skills competency, while the frequency describes the demographic profile. The independent sample T-Test demonstrates the equality of means and paired sample T-Test to describe the mean score differences in the pre and post academic performance. The regression analysis was conducted to examine the relationship between the attitudes and soft skills towards the subsequent academic performance.

\section{Findıngs}

\section{Demographics of Respondents}

In total, 247 questionnaires were distributed to internship employers via 247 accounting internship students and were collected at the end of the internship period. The employer is required to assess the student's performance using the Practical Training Evaluation Form for each student upon completing the sixmonth internship program. Nevertheless, data, based on 224 employer respondents, were analysed. As shown in Table 1, out of 224 respondents, 57 (25.5\%) were male while 167 (74.5\%) were female students. The majority of the students, 160 (71.4\%), had their internship in non-audit firms (classified as private and public limited companies) and 64 $(28.6 \%)$ in audit firms.

Table 1: Demographics of the respondents - Gender and Type of Firm

\begin{tabular}{|l|c|c|}
\hline Items & Frequency & Percentage \\
\hline Gender & & \\
Male & 57 & 25.5 \\
Female & 167 & 74.5 \\
\hline Firm & & \\
Audit & 64 & 28.6 \\
Non-audit & 160 & 71.4 \\
\hline
\end{tabular}

Table 2 presents the employers' assessment of the accounting internship students (trainees) in terms of their abilities on the level of supervision, their effort and initiative, their ability to perform work as directed and their independence. Employers can assess or rate whether the job task at the company is appropriate and suitable for the trainees' abilities. As shown in Table 2, the employers' assessment results indicated that 110 students (49\%) could perform work as directed. It is followed by 75 students (33.6\%) required little supervision and 33 $(14.6 \%)$ were able to work independently. The results also indicate that less than $10 \%$ lack initiative and require constant supervision or are over-dependent. It shows that employers' evaluation of trainees' abilities positively affects the students' attitudes during the internship period. 
Table 2: Trainee Ability

\begin{tabular}{|l|c|c|}
\hline Items & Frequency & Percentage \\
\hline Students/Trainees & & \\
Required constant supervision, over-dependent & 2 & .8 \\
The lacked initiative must be instructed from time to time & 4 & 2.0 \\
Performed work as directed & 110 & 49.0 \\
Required little supervision & 75 & 33.6 \\
Worked independently & 33 & 14.6 \\
\hline
\end{tabular}

\section{T-Test Analysis on Students' Attitudes and Soft Skills}

\section{Internship Program between Different Types of Employers (Non-Audit Firms and Audit Firms)}

T-Test analysis was conducted to examine any significant differences in the attitudes and skills of the students between the two types of employers; non-audit firms and audit firms. Table 3 provides the results of the T-Test analysis. Based on the mean scores, it shows a mixed result among all the attributes of attitudes and soft skills between audit and non-audit firms. Students undergoing the internship program in the audit firm scored higher mean for employers' marks, general skill \& motivation, interpersonal skills, responsibility, compliance with working requirements, trainee's knowledge and understanding of concepts, and ability to communicate own ideas. In the non-audit firm, higher mean score was given for job competency only. 
Table 3: Difference in Attitudes \& Soft Skills (Between Non-Audit and Audit Firms)

\begin{tabular}{|l|c|c|c|c|c|}
\hline & Firm category & $\mathbf{N}$ & Mean & Std. Deviation & $\begin{array}{c}\text { Std. Error } \\
\text { Mean }\end{array}$ \\
\hline \multirow{2}{*}{ Employer marks } & non-audit firm & 160 & 32.4312 & 4.38066 & .34632 \\
\cline { 2 - 6 } & audit firm & 64 & 33.2031 & 3.49685 & .43711 \\
\hline \multirow{2}{*}{ General skills \& motivation } & non-audit firm & 160 & 4.1594 & .64274 & .05081 \\
\cline { 2 - 6 } & audit firm & 64 & 4.3359 & .59798 & .07475 \\
\hline \multirow{3}{*}{ Interpersonal skills } & non-audit firm & 160 & 4.0281 & .67816 & .05361 \\
\cline { 2 - 6 } & audit firm & 64 & 4.0078 & .74265 & .09283 \\
\hline \multirow{2}{*}{ Responsibility } & non-audit firm & 160 & 4.3719 & .64731 & .05117 \\
\cline { 2 - 6 } & audit firm & 64 & 4.3828 & .60907 & .07613 \\
\hline \multirow{2}{*}{$\begin{array}{l}\text { Compliance with working } \\
\text { requirements }\end{array}$} & non-audit firm & 160 & 4.1875 & .75600 & .05977 \\
\cline { 2 - 6 } & audit firm & 64 & 4.3438 & .63543 & .07943 \\
\cline { 2 - 6 } & non-audit firm & 160 & 4.3844 & .52820 & .04176 \\
\hline \multirow{2}{*}{$\begin{array}{l}\text { Trainee's knowledge and } \\
\text { understanding of concepts }\end{array}$} & audit firm & 64 & 4.4844 & .48973 & .06122 \\
\cline { 2 - 6 } & non-audit firm & 160 & 3.7021 & .65886 & .05209 \\
\hline \multirow{2}{*}{$\begin{array}{l}\text { Ability to communicate own } \\
\text { ideas }\end{array}$} & non-audit firm & 64 & 3.7708 & .66634 & .08329 \\
\cline { 2 - 6 } & audit firm & 160 & 4.0234 & .67920 & .05370 \\
\hline
\end{tabular}

\section{T-Test Analysis on Students' Attitudes and Soft Skills}

\section{Internship Program between Different Genders (Male and Female)}

In examining the statistical significance of the changes in the results after the internship program, paired-samples T-Tests were conducted for both the male and female groups. As shown in Table 4, there is a significant difference in all the results for each attribute of attitude and soft skills. The results are consistent with the results of the overall analysis. Based on the mean scores, employers perceived that female students scored better on the employer's mark, the attitudes and soft skills possessed than male students. Moreover, the mean scores for both male and female students show an increase in performance after the internship. 
Table 4: Difference in Attitudes \& Soft Skills (Between genders)

\begin{tabular}{|l|c|c|c|c|c|}
\hline & Gender & $\mathbf{N}$ & Mean & Std. Deviation & Std. Error Mean \\
\hline \multirow{2}{*}{ Employer marks } & Male & 57 & 31.7302 & 4.90295 & .61771 \\
\cline { 2 - 6 } & Female & 167 & 33.1793 & 3.83761 & .28291 \\
\hline \multirow{2}{*}{ General skills \& motivation } & Male & 57 & 4.0873 & .74346 & .09367 \\
\cline { 2 - 6 } & Female & 167 & 4.2446 & .60955 & .04494 \\
\hline \multirow{2}{*}{ Iob competency } & Male & 57 & 3.8333 & .76727 & .09667 \\
\cline { 2 - 6 } & Female & 167 & 4.1005 & .67706 & .04991 \\
\hline \multirow{2}{*}{ Responsibility } & Male & 57 & 4.2540 & .62135 & .07828 \\
\cline { 2 - 6 } & Female & 167 & 4.4402 & .62219 & .04587 \\
\hline \multirow{2}{*}{$\begin{array}{l}\text { Compliance with working } \\
\text { requirements }\end{array}$} & Male & 57 & 4.1032 & .85269 & .10743 \\
\cline { 2 - 6 } & Female & 167 & 4.2880 & .65593 & .04836 \\
\cline { 2 - 6 } & Male & 57 & 4.3016 & .64314 & .08103 \\
\hline \multirow{2}{*}{$\begin{array}{l}\text { Trainee's knowledge and } \\
\text { understanding of concepts }\end{array}$} & Male & 57 & 3.6561 & .71333 & .08987 \\
\cline { 2 - 6 } & Female & 167 & 3.7772 & .63723 & .04698 \\
\hline $\begin{array}{l}\text { Ability to communicate own } \\
\text { ideas }\end{array}$ & Male & 57 & 3.9762 & .66556 & .08385 \\
\cline { 2 - 6 } & Female & 167 & 4.0938 & .60030 & .04425 \\
\hline
\end{tabular}

The difference between male and female students was further analysed using an independent t-test and Lavene's Test for equality of variance to examine any significant differences. The results are presented in Table 5 below. The variations within the results of the male and female students were measured as shown by the sig. 2 tailed at significance level $\mathrm{p}<0.05$. The difference is significant only for job competency $(0.010)$, interpersonal skills $(0.041)$, and compliance with working requirements $(0.026)$.

Bedah AHMAD, Nadiah ABD HAMID, Zarinah ABDUL RASITT and Norazian HUSSİN, Journal of Southeast Asian Research, DOI: 10.5171/2021.718716 
Table 5: Summary of Levene's test and Independent Sample T-Test

\begin{tabular}{|l|c|c|c|c|c|}
\hline & \multicolumn{2}{|c|}{$\begin{array}{c}\text { Levene's Test for } \\
\text { Equality of } \\
\text { Variances }\end{array}$} & \multicolumn{3}{|c|}{ t-test for Equality of Means } \\
\hline & $\mathrm{F}$ & Sig. & $\mathrm{t}$ & $\mathrm{df}$ & Sig. (2-tailed) \\
\hline Employer marks & 9.754 & .002 & -2.402 & 245 & .017 \\
\hline General skills \& motivation & 2.143 & .145 & -1.668 & 245 & .097 \\
\hline Job competency & 3.066 & .081 & -2.611 & 245 & .010 \\
\hline Interpersonal skills & .030 & .863 & -2.051 & 245 & .041 \\
\hline Responsibility & .726 & .395 & -1.782 & 245 & .076 \\
\hline $\begin{array}{l}\text { Compliance with working } \\
\text { requirements }\end{array}$ & 12.612 & .000 & -2.234 & 245 & .026 \\
\hline $\begin{array}{l}\text { Trainee's knowledge and } \\
\text { understanding of concepts }\end{array}$ & 2.078 & .151 & -1.262 & 245 & .208 \\
\hline Ability to communicate own ideas & 1.871 & .173 & -1.304 & 245 & .193 \\
\hline
\end{tabular}

Regression Analysis - Multiple Linear Regression

means that $52.1 \%$ of the variation in CGPA part 8 is explained by the students' performance regarding general skills \& motivation, job competency, interpersonal skills, responsibility, compliance with working requirements, trainee's knowledge and understanding of concepts, and ability to

The results of the regression analysis are discussed as follows. Based on the results showed in Table 6 , the $\mathrm{R}$ Square is .722 . It communicate own ideas.

Table 6: Model Summary of Regression

\begin{tabular}{|c|c|c|c|c|}
\hline Model & R & R Square & $\begin{array}{c}\text { Adjusted R } \\
\text { Square }\end{array}$ & Std. Error of the Estimate \\
\hline 1 & $.722^{\mathrm{a}}$ & .521 & .505 & 4.68130 \\
\hline
\end{tabular}

a. Predictors: Responsibility, Compliance with working requirements, Ability to communicate own ideas, Interpersonal skills, Job competency, Trainee's knowledge and understanding of concepts, General skills \& motivation

Bedah AHMAD, Nadiah ABD HAMID, Zarinah ABDUL RASIT and Norazian HUSSIN, Journal of Southeast Asian Research, DOI: 10.5171/2021.718716 
Paired Samples T-Test Analysis

The Effect of Internship Program on Subsequent Academic Performance
Table 7 shows the mean score for the CGPA pre and post internship. The pre is CGPA P6 and the post is CGPA P8. The results show that the pair between pre and post is significant at $(p<0.05)$. It indicates that attitudes and soft skills affect the students' performance before and after the internship.

Table 7: Paired Samples T-Test

\begin{tabular}{|c|c|c|c|c|c|c|c|c|}
\hline \multicolumn{2}{|c|}{ Paired Differences } & t & df & $\begin{array}{c}\text { Sig. } \\
\text { (2- } \\
\text { taile } \\
\text { d) }\end{array}$ \\
\hline \multicolumn{2}{|c|}{$\begin{array}{c}\text { 95\% } \\
\text { CGPA P8 } \\
\text { CGPA P6 }\end{array}$} & Mean & S.D. & $\begin{array}{c}\text { S. E. } \\
\text { Confidence } \\
\text { Interval of the } \\
\text { Difference }\end{array}$ & Lower & Upper & & \\
\hline & .04682 & .06289 & .00404 & .03885 & .05478 & 11.581 & 241 & .000 \\
\hline
\end{tabular}

The findings revealed that most employers agreed that the accounting students who underwent the internship at their organizations possessed positive attitudes and soft skills such as responsibility, compliance with the working requirements, interpersonal skills, job competency, and general skills. The findings are also supported by previous studies on soft skills among accounting students (Kavanagh and Drennan, 2008; Maelah et al., 2012; Moghaddam, 2014; Mohaidin et al., 2016).

\section{Conclusions}

The research identified the differences in students' attitudes and soft skills between different types of internship employers: audit firms and non-audit firms. The employers' assessment of students' attitudes and soft skills include general skills and motivation, job competency, interpersonal skills, responsibility, compliance with working requirements, and communication ability. Except for job competency, other types of attitudes and soft skills are better for students undergoing internship programs in audit firms compared to non-audit firms. Regarding the comparison between genders, the research provides evidence that females have improved their attitudes and soft skills better than male students. The study also revealed that the attitudes and soft skills acquired during the internship affect the subsequent academic performance, which is consistent with previous studies (Ebeid, 2004; Martin and Wilkerson, 2006; Thilakerathne and Madurapperuma, 2014; Mohd Nor and Ismail, 2015).

The findings of employers' assessment relevance to accounting internship students' attitudes and soft skills performance will provide the university with necessary insights to further improve and strengthen the accounting program to suit the employers' requirements. An effective internship program will benefit the stakeholders, as the university generates better market oriented graduates which will increases the 
employability rate. Employers would also benefit from the internship program as they may have the opportunity to identify potential employees without providing earlier training and hence, reducing the cost of re-training employees. Students gain most of the internship program's benefits as they can expand their knowledge and skills, gain experience in a real-world working environment, get a future direction on careerrelated choices, and forge networking with personnel in the host organization.

This study is subjected to several limitations. The sample population used is from a single university's accounting students, using only one batch group. It may not be sufficient to generalize the findings of this study to other courses, faculties, or the overall higher education. This study suggests that future research should focus on the impact of internship across the faculties or universities in a comparative study to provide more meaningful insights in the broader perspective. It should include several batches of students to examine the trend of internship programs towards students' developing skills and academic performance as another fruitful area for future research.

\section{References}

- Abel, J., Deitz, R. and Su, Y. (2014), 'Are Recent College Graduates Finding Good Jobs?' Current Issues in Economics and Finance, 20, 2-8

- Adebakin, A.B. (2015), 'Does Internship Experience Beget Academic Relevance and Employment Prospects: An Assessment of Graduate Interns from A Nigerian University.' Bulgarian Journal of Science and Education Policy (BJSEP), 9(2), 302-316.

- Albu, N., Calu, D.A. and Raluca, G. (2016). 'The Role of Accounting Internships in Preparing Students' Transition from School to Active Life.' Accounting and Management Information Systems, 15(1), 131-153.
- Anjum, S. (2020), 'Impact of Internship Programs on Professional and Personal Development of Business Students: A Case Study from Pakistan.' Future Business Journal, 6(2), 1-13.

- Bedah, A., Mat Dangi, M.R., Nurul Huda, A.R., Nur Adura, A.N. and MohdAfiq, A. (2018), 'Does Accounting Internship Affect Students' Knowledge, Soft Skills and Personal Quality?'Advanced Science Letters, 24(4), 2252-2256.

- Bukaliya, R., (2012), 'The Potential Benefits and Challenges of Internship Programs in An ODL Institution: A Case for the Zimbabwe Open University.' International Journal on New Trends in Education and Their Implications, 3(1), 118-133.

- Cheng, Y.Y., Chien, C.C. and Wang, S.J (2016), 'The Effect of the Accounting and Business Curriculums on Creativity.' Journal of Curriculum and Teaching, 5(2), 127-143.

- Chu, S.K.W and Kwan, A.C.M. (2012), 'Blogging for Information Management, Learning, and Social Support During Internship.' Journal of Educational Technology \& Society, 15(2), 168-178.

- Dasar Latihan Industri InstitusiPengajian Tinggi (2010), Kementerian Pengajian Tinggi, Malaysia.

- Ebeid, H. (2004), 'An Empirical Investigation of The Impact of The Student Accounting Internships on Subsequent Academic Performance: The Case of UAE University.' Journal of Economic and Administrative Sciences, 20(2), 33-44.

- Hadiyanto and Ibrahim, M.S. (2013), 'Students' Generic Skills at The National University of Malaysia and The National University of Indonesia.' Procedia - Social and Behavioral Sciences, 83, 71-82.

- Heang, L.T., Ching L.C., Mee, L.Y and Huei, C.T. (2019), 'University Education and Employment Challenges: An Evaluation of Fresh Accounting Graduates in Malaysia.' International Journal of Academic Research in Business and Social Sciences, 9(9), 1061-1076.

Bedah AHMAD, Nadiah ABD HAMID, Zarinah ABDUL RASIT and Norazian HUSSIN, Journal of Southeast Asian Research, DOI: 10.5171/2021.718716 
- Hurst, J.L. and Good, L.K. (2010), 'A 20Year Evolution of Internships: Implications for Retail Interns, Employers and Educators.' The International Review of Retail, Distribution and Consumer Research, 20(1), 175-186.

- Ismail, N., Rasit, Z.A., Ali, N. and Mat Dangi, M.R., (2016), 'Academic Achievement of Bachelor Accounting Students: A Study on Attributes of High Achievers.' In Proceedings of the 27th International Business Information Management Association Conference-Innovation Management and Education Excellence Vision 2020: From Regional Development Sustainability to Global Economic Growth, IBIMA2016, International Business Information Management Association, IBIMA, 2595-2599.

- Ismail, N., Rasit, Z.A., Ali, N. and Mat Dangi, M.R. (2020), Admission Pathway and Performance in the Bachelor of Accounting Program.' Journal of Critical Reviews, 7(18), 914-923.

- Ismail, Z., Ahmad, A.S. and Ahmi, A. (2020), 'Perceived Employability Skills of Accounting Graduates: The Insights from Employers.' Ilkogretim Online Elementary Education Online, 19(4), 3641.

- Jackling, B and Natoli, R. (2015), 'Employability Skills of International Accounting Graduates; Internship Providers' Perspectives.' Journal of Education + Training, 57(7), 757-773.

- Jawabri, A. (2017), 'Exploration of Internship Experience and Satisfaction Leading to Better Career Prospects among Business Students in UAE.' American Journal of Educational Research, 5(10), 1065-1079.

- Kavanagh, M.H and Drennan, L. (2008), 'What Skills and Attributes Does an Accounting Graduate Need? Evidence from Student Perceptions and Employer Expectations.' Journal of Accounting and Finance, 48(2), 279-300.

- Knechel, W.R. and Snowball, D. (1987), 'Accounting Internship and Subsequent Academic Performance: An Empirical
Study.' The Accounting Review, 62(4), 799-807.

- Maelah, R., Aman, A., Muhammadun, M.Z. and Ramli, R. (2012), 'Enhancing Soft Skills of Accounting Undergraduates Through Industrial Training.' Procedia Social and Behavioral Sciences, 59, 541549.

- Maelah, R., Aman, A., Muhammadun, M.Z. and Ramli, R. (2014), 'Internship for Accounting Undergraduates; Comparative Insights from Stakeholders.' Journal of Education + Training, 56(6), 482-502.

- Martin, D.R and Wilkerson, J.E. (2006), 'An Examination of the Impact of Accounting Internships on Student Attitudes and Perceptions.' The Accounting Educators' Journal, XVI, 129138.

- Moghaddam, J.M. (2014),'Impacts of Internships on Students' Personal/Business Values and the Role of Their Personality Traits.' The Journal of Global Business Management, 10(1), 5260.

- Mohaidin, N.J., Supar, M., Ibrahim, M.A. and Jaafar, M.H. (2017), 'Employers' Perception on Internship Program.' SHS Web of Conferences 36, 2016 ICGA, DOI: 10.1051/shsconf/20173600010.

- MohdJaffri, A.B., Harun, R.J., Yusof, K.N and Tahir, I.M. (2011), 'Business and Accounting Students Perceptions on Industrial Internship Program.' Journal of Education \& Vocational Research. 1(3), 72-79.

- Mohd Nor, M. and Ismail, S. (2015), 'Effect of Industrial Training on Academic Performance: Evidence from Malaysia.' Journal of Technical Education and Training, 7(2), 44-53.

- Paisey, C. and Paisey, N. (2010), 'Developing Skills via Work Placements in Accounting: Student and Employer Views.' Accounting Forum, 34, 89-108.

- Penafort, F and Ahmad, B. (1997), 'Employers' Expectations on Today's Accounting Profession; A Malaysian Case Study.' Asian Review of Accounting, 5(2), 78-97.

Bedah AHMAD, Nadiah ABD HAMID, Zarinah ABDUL RASIT and Norazian HUSSIN, Journal of Southeast Asian Research, DOI: 10.5171/2021.718716 
- $\quad$ Rose, P.S. (2017), 'The Intern to Employee Career Transition.' Journal of Career Development, 1-14.

- Thilakerathne, P.M.C. and Madurapperuma, M.W. (2014), 'An Examination of Accounting Internship on Subsequent Academic Performance.' International Journal of Economics, Finance and Management Sciences. 2(1), 8-15.

- Thirumanickam, N. and Ahmad, B. (2013), 'Performance Measurement System in Higher Educational Institutions in Malaysia: An Exploratory Study of the Implementation of Balanced Scorecard.'
Asia Pacific Management Accounting Journal, 8(2), 149-173.

- Washor, K.S. (2015), 'Bridging the SoftSkill Gap from Education to Employment Through Internship.' PhD Dissertation, Paper 318. http://digitalcommons.uri. edu/oa_diss/318.

- Yusof, N., Mohd. Amin, M., Arshad, M., Dahlan, M.H and Mustafa, N. (2012), 'Authentic Assessment of Industrial Training Program: Experience of UniversitiTeknologi Malaysia.' Procedia Social and Behavioral Sciences, 56, 724 729.

Bedah AHMAD, Nadiah ABD HAMID, Zarinah ABDUL RASIT and Norazian HUSSIN, Journal of Southeast Asian Research, DOI: 10.5171/2021.718716 